\title{
コンパクトシティ政策が民生・交通部門の エネルギー消費量に与える影響に関する研究
}

\author{
中井 秀信 $^{1} \cdot$ 森本 章倫 $^{2}$ \\ 1正会員 東京電力株式会社 建設部 土木・建築技術センター 都市土木技術グループ 副長 \\ （干100-8560＼cjkstart東京都千代田区内幸町1-1-3） \\ E-mail:NAKAI.Hidenobu@tepco.co.jp \\ 2正会員 宇都宮大学准教授 工学部 建設学科 \\ （†321-8585 杤木県宇都宮市陽東7-1-2） \\ E-mail:morimoto@cc.utsunomiya-u.ac.jp
}

\begin{abstract}
本論文は，環境負荷低減を目指したコンパクトシティを指向し，郊外から都心部への移住をシナリオと して想定した場合，どのような居住形態（戸建または集合住宅）・家族形態（単身世帯，夫婦世帯，3世代 居住等）が都心に移住すればエネルギー消費低減に寄与するかをシミュレーションした。具体的には民生 部門では電力消費量に着目し, 住宅種別や世帯人員等, ライフスタイル別の相違を把握し，コンパクトシ ティ政策時の予測を行った。運輸部門では現状推移・コンパクトシティ政策時の交通需要推計を行い, エ ネルギー消費量の算出を行った。この結果，コンパクトシティ政策により，運輸・民生両部門で，エネル ギー消費量低減効果が確認できたことから，この両部門での総合評価を実施した点に本研究の特色がある.
\end{abstract}

Key Words: compact city, energy consumption, environmental load reduction

\section{1. はじめに}

\section{(1) 背景·目的}

2005年2月に京都議定書が発効になり, 二酸化炭素排出 量削減の必要性が迫られている中, とりわけ, 運輸部門・ 民生部門での二酸化炭素排出量増加が顕著となっており, 関係各所で具体的な削減方策を模索している状況にある このような中，二酸化炭素排出量削減を中心とした環境 負荷削減に向けた取組みは，サステナブルな都市を構築 するための重要な課題となっている.

そこで本研究では，民生部門においては家庭部門の電 力消費量，運輸部門においては自動車のエネルギー消費 量を取り上げ，近年，環境負荷の少ない都市形態として 注目されている“コンパクトシティ”に着目し，その政 策によるエネルギー消費低減効果を家庭部門・運輸部門 の両方から検討していく，その上で，エネルギ一負荷低 減のために有効な都市政策について言及寸ることを目的 としている.

\section{（2）交通部門の環境負荷研究}

コンパクトシティが交通部門の環境負荷低減に寄与 するかについては，これまでに様々な研究がなされてき
た. 最も古典的なものとしてNewman \& Kenworthy ${ }^{1)}$ に よる人口密度とガソリン消費量の関係を図化したものが 挙げられる. 都市単位で見た場合, 人口密度の上昇が交 通エネルギー消費を下げるとの調查結果を明らかにした ことは，この分野の研究の先駆けともいえる. しかし, その後, 都市内部の状況を詳しく見ると, 必ずしも人口 密度の上昇が環境負荷削減に結びつかないことが指摘さ れている. Bouwman ${ }^{2}$ はオランダの都市を対象にした調 查で, 都心部の混雑悪化による移動効率の悪化を加味す ると，都市化地域と田園地域に大差はないと報告してい る. また, Brindle ${ }^{3)}$ はNewmanらの分析手法そのものの問 題を指摘し, コンパクト化について疑義を提起している. 例えば, 人口密度は人口／面積, 1 人当たりのガソリン消 費量はガソリン消費量/人口となっているため, 同じ人 口変数が2変数の分子と分母に現れる. そのため, ガソリ ン消費量の大小に係らずある程度の負の相関が現れるこ とを指摘している. しかし，この指摘に対して鈴木・室 町 $^{4}$ は，仮に人口変数を外して比較しても有意な関係が 現れることを示している．わが国においても，交通部門 の環境負荷推計に関する研究に着目寸ると，これまで数

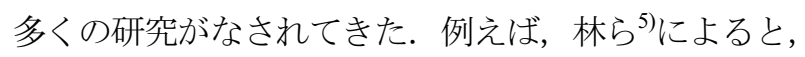
世界各都市の都市比較を行った結果, 人口密度の上昇は1 
人当たりのエネルギー消費量を下げるとしている．しか し一方で，人口密度が上昇するほど単位面積当たりの交 通エネルギー消費量が増大し，局地的な環境負荷が悪化 する分析結果も紹介している. 同様の研究成果は, 谷口 $ら^{6}$ にによる全国67都市の分析結果からも試算されており， 市街化区域の人口密度の高い都市ほど 1 人当たりのガソ リン消費量が少ないとしている.

また，都市構造との関係については，森本・古池》が， 全国78都市を対象にした分析の結果，交通エネルギー消 費量と住宅地や工業地の分布パターンに関連性があるこ とを示した. 都市面積に関しては，小根山・大西8 ${ }^{8}$ は, 日本の 24 都市の分析から都市面積が大きくなると 1 人当 たりの $\mathrm{CO}_{2}$ 排出量が小さくなることを示した. さらに, 堀ら 下し，エネルギー消費量削減効果も大きくなることを明 らかにした。

大都市圈に関する研究としては, 森本ら ${ }^{10}$ は, 都心育 成施策の有效性を示寸一方で，現状の交通状況を前提と した核都市育成は，自動車利用の増大によって，総量的 に交通負荷が高まるとの試算を紹介している．また，京 阪神都市圈の推計結果として, 北村ら ${ }^{11)}$ は，高密度で職 住近接型の土地利用促進が効果的であるとしながら，都 市圈外縁部に居住し長距離通勤を行う世帯に対寸る政策 の必要性を述べている.

さらに，コンパクトシティに関する研究としては，佐 保 ${ }^{12}$ は，コンパクト性が高いことを「都市機能の集積圈 域が相対的に小さくその密度が高い状態」とし，都市の 類型化を試みている.これより，都市機能の集積圈域と 集積密度の二つの限定した視点ではあるが，コンパクト 性による都市構造の評価が行われた。コンパクト性の高 い都市はDID内部の機能の集積密度が高く, 求心性の高 いパターンを示している. また，森本 ${ }^{13} 1$ は, コンパクト な市街地に望まれる土地利用と交通の関係を概説してい る. 現状のコンパクトな都市では公共交通利用や徒歩・ 自転車等の利用により，自動車型都市と比べて環境に優 しい都市となっている。しかし，自動車利用の増大や土 地利用の郊外化は寸べての都市においてみられ，年々環

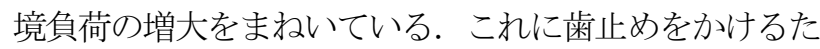
めには，もう一度都市内の土地利用と交通の関係を再認 し，抜本的な見直しと整理が必要であるとしている.

総じて，人口密度の上昇が交通の環境負荷に与える影 響には様々な視点がある．都市のコンパクト化や人口密 度の上昇は，一般的には環境に優しいとされているが, 個別の都市での評価をするためには，都市の内部の土地 利用状況や交通環境などをより詳細に検討寸る必要があ る.

\section{（3）民生部門の環境負荷研究}

民生部門のエネルギー消費量に注目すると, 石田 ${ }^{14)}$ は, 戸建住宅のエネルギー消費実態とエネルギー消費構造を 明らかにしている，照明用・調理用・給湯用・暖房用・ 冷房用と用途毎に分析し，エネルギー消費には，延床面 積や世帯人員などが影響していることを示している．ま た，鈴木 ${ }^{15)}$ は，人口 20 万人以上の全国 84 都市の電力・ガ ス等の 1 人当たりのエネルギー消費量を算出し, 都市特性 との関連性を分析している。 その中で対象とした都市で の1人当たりの消費量は全国平均の水準より少ないとし ている。

概して民生部門のエネルギー推計については，世帯単 位や都市間比較の研究はいくつか見られるが，都市内部 の民生エネルギーの消費実態を明らかにした研究は極め て少ない．これは，地区単位でのデータ集計が極めて困 難であるせいでもある。このようなデー夕制約下で，今 村ら ${ }^{16}$, 石森ら ${ }^{17)}$ は1人当たりの電力消費量を地区単位 に集計し，都心において郊外より高い值を示すことを示 した. その原因として，都心と郊外で住宅形態や世帯人 員などのライフスタイルの特徵が違い，それらが電力消 費量に影響を及ぼすことを明らかにした。

このようにライフスタイルが環境に与える影響は，近 年交通部門でも報告されており，中道ら ${ }^{18)}$ は，交通部門 の環境負荷においても，行動タイプが与える影響が大き いことを指摘している．郊外居住者が都心部に移住した としても, 自動車依存の生活から脱却しなくては環境負 荷低減に結びつきにくいと類推している.

\section{(4) 本研究の位置づけ}

コンパクトシティと環境負荷の関連性については，両 者の定量的な把握から始まり，近年では都市居住者の生 活スタイルにまで言及した研究が見られるようになった。

また，民生部門と交通部門の双方を計算し，その比較 を行っている研究は限られている. 僅かな例として, 田 頭 ${ }^{19}$ は民生エネルギーと交通エネルギーの双方を計算し， 低密度都市を高密度都市に変えることが必ずしも良いと は限らないとしている．特に，トリップ長の短い都市で は低密度都市を目指寸のも一つの選択肢と提案している。 また，今村ら ${ }^{16)}$ の研究でも，郊外居住者がより多くの交 通エネルギーを消費することが確認されているが，民生 部門においては逆転する結果も算出されている.一方で, 首都圈を対象とした国土交通政策研究所の分析 ${ }^{20)}$ では, $\mathrm{CO}_{2}$ 排出量の減少は産業構造転換による産業部門からの 減少が大きく寄与するとしながら，分散型の土地利用は $\mathrm{CO}_{2}$ 排出の観点から望ましくないとしている．また，仙 台を対象とした分析 21 - では, 都心居住型の都市構造を構

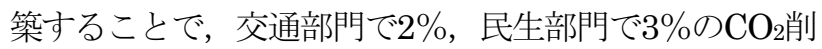


減効果があると試算している.

これまでの研究成果を踏まえると，コンパクトシティ の形成が環境負荷に必ずしも好影響だけを与えるとはい えない22). 特に, 住宅種別や世帯人員等, ライフスタイ ルの違いによって，環境負荷に与える影響は異なってく るため, コンパクトシティ政策の評価をより詳細にかつ, 都市あるいはあるエリア全体での環境負荷を検討寸るた めには，民生部門と交通部門を合わせた総合的な視点が 必要となる.

そこで本研究は，民生及び交通の両部門を対象にライ フスタイルを反映したシナリオを設定し，市町村単位よ り更に細かい地区レベルでのデータを収集し，これまで 不明瞭であった両者の関連性を詳細に検討している点に 特色がある.

\section{2. 宇都宮市のエネルギ一消費量}

\section{(1) 電力消費量の現状}

一般家庭で消費される電力を主に電灯という注 1 が，宇 都宮営業所管内では 1992 年から 2002 年にかけての 10 年間で電灯使用量は 1.36 倍, 契約口数は 1.19 倍の伸びを 示している. 一方で, 10 年間の宇都宮市における人口の 伸びは 1.03 倍であり, 人口の伸びに対して電力消費量の 伸びが顕著である. 表-1 において 1992 年と 2002 年の 1 人当たり電力消費量を比較すると, 10 年間で 1 人当たり $464 \mathrm{kWh}$ の消費量が増加していることが分かる．この原 因としては，家電製品の普及が第一に挙げられるが，居 住形態の変化も,一つの要因として考えられる.

ここで，宇都宮市の電力供給データ(H14 年度実績)の 内の従量電灯 A・B での消費量を用いて宇都宮市の町別 居住人口 1 人当たりの電力消費量を図-1 に示寸. このと

表-1 宇都宮市における 1 人当たり年間電灯消費量の変化

\begin{tabular}{|c|c|r|r|}
\hline 年 & 人口 & 電灯 $(\mathrm{MMh})$ & 1人当たり電灯消費量 $(\mathrm{kWh} /$ 人) \\
\hline 1992 & 431,879 & 624,665 & 1,446 \\
\hline 2002 & 446,092 & 852,033 & 1,910 \\
\hline
\end{tabular}

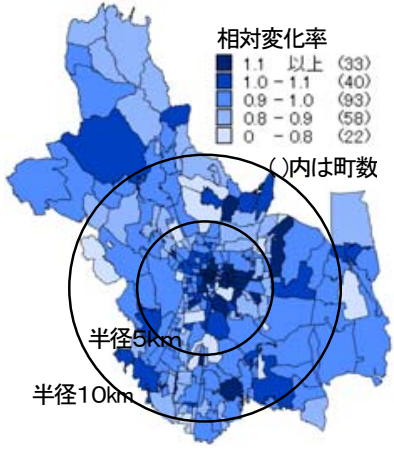

図-1 1 人当たりの電力消費 量相対変化率(年間)

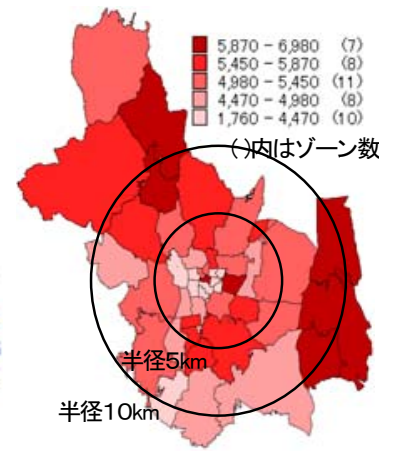

図-2 4 目的自動車エネルギー 消費量 $(\mathrm{kcal} /$ 人・年 $)$
き，平均值は $1,562(\mathrm{kWh} /$ 人)となり，この值を 1 とした相 対変化率を用いて表示寸る. これより, 都心部で高く, また, 郊外でも一部の地域で高い值を示寸ことが分かる.

\section{(2) 自動車エネルギ一消費量の現状}

全国 PT 調查(平成 11 年)では, 宇都宮市における運輸 部門の総エネルギー消費量は $7,872(\mathrm{kcal} /$ 人)であり，その うち自動車によるエネルギー消費量は 7,587( kcal/人)であ る.つまり，運輸部門のエネルギー消費量の大部分は自 動車エネルギー消費量であり，96.4\%も占めている。 こ こで, 平成 4 年の宇都宮都市圈 PT 調査での通勤・通学・ 讳宅・私事 4 目的による自動車エネルギー消費量を図-2 に表す，都心で低く，郊外に行くにつれ高い值となる傾 向を示している.

\section{3. 家庭部門のエネルギ一消費量推計方法}

\section{（1）民生部門（電力消費量）の推計}

\section{a) ライフスタイル調査結果に基づく推計}

各家庭における電力消費量の差は, 住宅種別や世帯人 員等，ライフスタイルの特徵が原因であると考える. よ って，住宅種別や家族構成の違いによる電力消費量の差 異を把握するため, ライフスタイル調查主 2 を行った. 調 查概要を表-2 に示寸.

この調査結果をもとに, 1 年間の各家庭での電力消費 量（実績）を基に算出した各種家庭電力消費量原単位を 表-3に示す.

これより，同じ家族構成においても集合住宅に比へ， 戸建住宅の電力消費量が多く，また，世帯人員が少ない 家族形態ほどその差が大きい. 住宅の立地条件にかかわ らず，世帯当たりの占有面積が少なく，家族での共有面

表-2 ライフスタイル調査概要

\begin{tabular}{|c|c|}
\hline 調査日時 & 2004年10月～11月 \\
\hline 調査方法 & $\begin{array}{l}\text { a)学内調査 b)戸別訪問調査 c)その他 } \\
\text { の機関への依頼 }\end{array}$ \\
\hline 有効票数 & 125票 \\
\hline 調査項目 & \begin{tabular}{|l} 
住宅種別·床面積·世帯人員·家族構成· \\
昼間の在宅状況·暖房等の熱源等
\end{tabular} \\
\hline 電力消費量 & 「依頼書」を提出し, 東京電力より入手 \\
\hline
\end{tabular}

表-3 世帯当たりの年間電力消費量原単位 $(\mathrm{kWh} /$ 世帯)

\begin{tabular}{|c|c|c|c|c|c|c|}
\hline \multirow{2}{*}{ 原単位(kWV/年) } & \multicolumn{3}{|c|}{ 戸建住宅 } & \multicolumn{3}{|c|}{ 集合住宅 } \\
\hline & 平均値 & 標準偏差 & デー数 & 平均値 & 標隼偏差 & デー数 \\
\hline 単身世帯 & 3,559 & 1,511 & 3 & 1,707 & 582 & 23 \\
\hline 夫婦世帯 & 5,201 & 2,216 & 22 & 2,316 & 238 & 6 \\
\hline 夫婦之子供世帯 & 5,330 & 2,017 & 37 & 4,057 & 2,406 & 14 \\
\hline 三世代以上世帯 & 7,099 & 2,834 & 20 & 注 $3 * 5,403$ & - & - \\
\hline
\end{tabular}




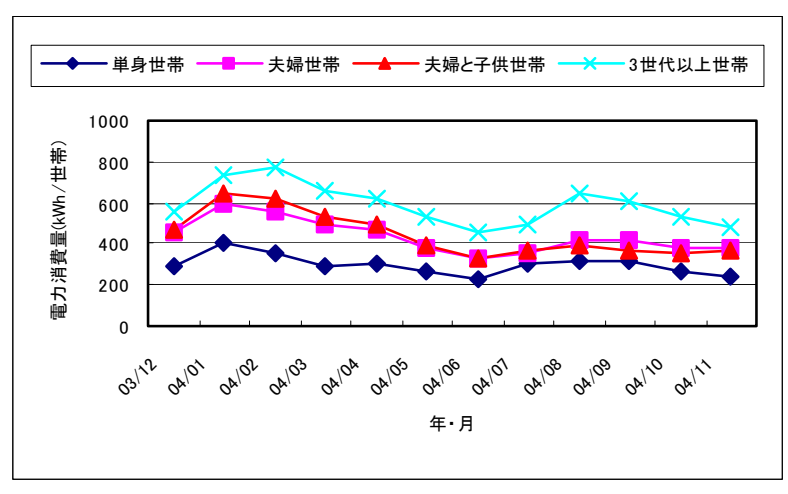

図-3 戸建住宅の年間変動

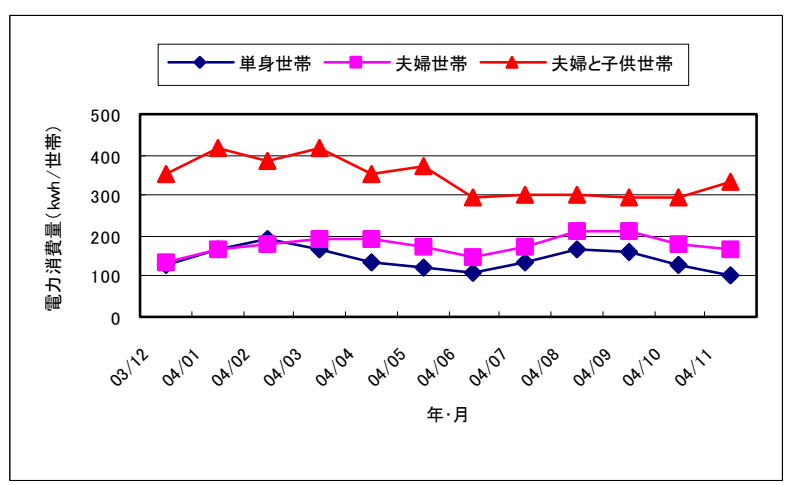

図-4 集合住宅の年間変動

積が増えると，電力消費量は少なくなると推測される. つまり，戸建住宅に住む単身世帯や夫婦世帯は，電力 消費量の観点からは非効率的であることが分かる。また, それらの年間変動を住宅形態別に図-3 および図-4 に表 す.これより，家庭部門の電力消費量のピークは，夏で はなく冬にあることが分かる。

\section{(2) 運輸部門のエネルギ一消費量推計方法}

\section{a) 交通需要推計モデルの構築}

本研究では，運輸部門のエネルギー消費量推計に原単 位法を用いる ${ }^{23)}$. これは交通手段別に推計されたエネル ギー原単位に手段別トリップ長を乗ずることで算出され， 都市全体の推計をする場合に用いられることが多い注4.

なお，手段別トリップ長の推計には，マクロ交通流シ ミュレーターTransCAD4.024)を用いる. TransCAD4.0 は交 通需要予測モデルが含まれており, 本研究では四段階推 定法のうち発生集中, 分布, 機関分担の予測に用いた. この時, 対象は宇都宮市 44 計画基本ゾーン, 評価年次は 2020 年と設定する. 本研究では，コンパクトシティ政策 実施時の居住地のあり方を検討するため, 交通目的の中 でも特に居住地に起因するものを対象とした。

\section{b) 集中交通量の予測}

一般に居住地から発生するトリップは通勤や通学，あ るいは私事目的として生まれ，トリップ目的が完了する と帰宅トリップとなって居住地に戻ってくる. 居住地か
表-4 帰宅集中交通量予測の結果 $\left(\mathrm{R}^{2}=0.962\right)$

\begin{tabular}{|c|c|c|c|}
\hline 説明変数 & 偏回帰係数 & 標準偏回帰係数 & T值 \\
\hline \hline 単身十夫婦世帯数 & 1.35 & 0.324 & 5.405 \\
\hline${ }^{*}$ 核家族以上世帯数 & 3.247 & 0.687 & 11.449 \\
\hline 定数項 & 565.396 & - & 1.87 \\
\hline
\end{tabular}

ら 1 施設への往復ならば発生も集中も基本的に同じで, どちらのトリップを対象としてエネルギー推計をしても 構わない. しかし，私事目的のように複数の施設を回遊 する場合もあり，必ずしも居住地に起終点があるとは限 らない.

そこで本研究では, 必ず居住地に関与する帰宅目的卜 リップに着目する.このトリップの発生は事務所・工場等 の勤務先や学校，スーパーやデパートなどの商業施設で あり，集中は各家庭である。つまり，ここではコンパク トシティ政策が居住地を変化させ，それによって帰宅卜 リップが変化すると考え，集中交通量の予測を行う．各 ゾーンにおける集中量の推計には，世帯特性を考慮した 表-4 に示寸回帰モデル法を用いた.

\section{c) 分布交通量の予測}

分布交通量の推計には，交通発生・集中の影響を考慮 することができる始終点制約型の重力モデル式(1)を用 いる. この時, 交通抵抗 $\left[d_{i j}\right]$ としてゾーン間距離を用い, 交通抵抗関数 $\left[f\left(d_{i j}\right)\right]$ のパラメータ推計を行った(式(2)参 照). なお，世帯特性や勤務先等の要因は, ゾーン単位に 集計された発生集中交通量を介在して, OD 交通量とし て表現される.

$$
\begin{gathered}
T_{i j}=A_{j} \cdot \frac{P_{i} \cdot f\left(d_{i j}\right)}{\sum_{\text {allzone }} P_{z} \cdot f\left(d_{i j}\right)} \quad T_{i j}=P_{i} \cdot \frac{A_{j} \cdot f\left(d_{i j}\right)}{\sum_{\text {allzone }} A_{j} \cdot f\left(d_{i j}\right)} \\
f\left(d_{i j}\right)=d_{i j}^{-b} \quad(b=4.7762)
\end{gathered}
$$

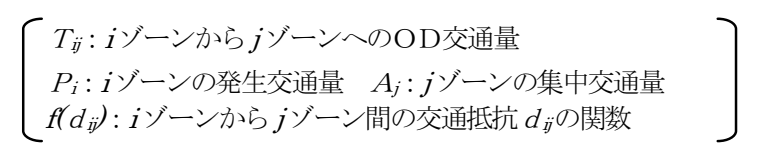

\section{d) 機関分担率の予測}

交通機関分担率の推計には，交通機関の効用差を考え た集計ロジットモデル・バイナリーチョイス型を用いる こととする. 以下の図-5に示すように，2段階に分けて 自動車の分担率 $(=$ Ptrans $\times$ Pcar $)$ を推計する. また, 自動車 (Pcar)の推計式を式(3)に記す.

$$
\begin{array}{r}
P_{c a r}=\frac{\exp \left(Z_{c a r}\right)}{\exp \left(Z_{c a r}\right)+\exp \left(Z_{\text {mass }}\right)}=\frac{1}{1+\exp \left(Z_{\text {mass }}-Z_{c a r}\right)} \\
{[Z \text { : 各交通機関の効用, mass : 公共交通 } c a r: \text { 自動車 }]}
\end{array}
$$


ここで, 分布交通量と自動車分担率より 1992 年の自動車 交通量の OD 表再現を行ったところ，現況との相関は $\mathrm{R}=0.730$ となった.

また，パラメータ推計を行った結果，交通機関選択確 率(Ptrans)および自動車選択確率(Pcar)の説明要因を表-5 および6に示す.

\section{e) エネルギ一消費量の算出}

予測された OD 表を基にして式(4)に従い，市内 44 の 計画基本ゾーンごとに着地ベースの自動車エネルギー消 費量を算出する.

$$
\sum_{j} t_{i j}=\sum_{j} G_{i j} \times T_{i j} \times S \times e
$$
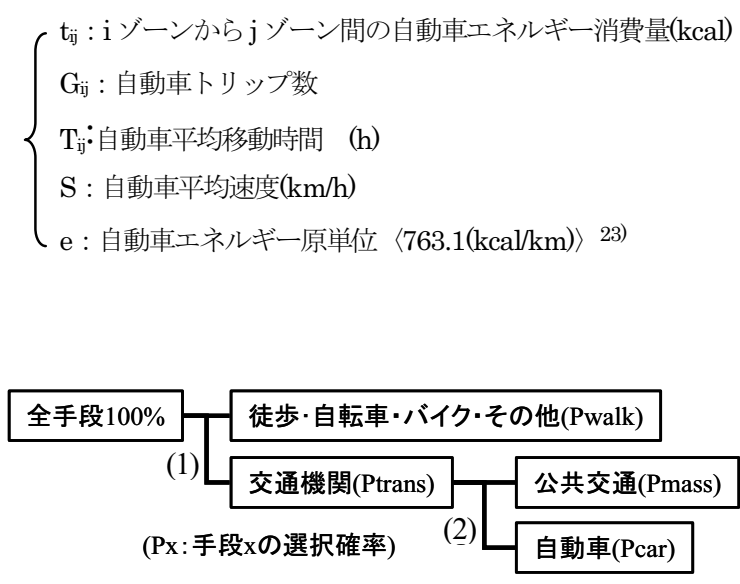

図-5 集計ロジットモデル・バイナリーチョイス型の概念

表-5 交通機関選択確率(Ptrans)の説明要因

\begin{tabular}{|c|c|c|c|}
\hline 説明変数 & 偏回帰係数 & 標準誤差 & T値 \\
\hline ゾーン間距離(Log) & 1.329 & 0.109 & 12.142 \\
\hline 免許保有率 O & 2.744 & 1.589 & 1.728 \\
\hline 免許保有率 D & 2.943 & 1.539 & 1.912 \\
\hline 住宅密度 O & 1.661 & 1.050 & 1.582 \\
\hline 住宅密度 D & 1.204 & 0.921 & 1.307 \\
\hline 事務所密度 $\mathrm{O}$ & 2.485 & 0.984 & 2.526 \\
\hline 学校密度 O & -9.795 & 2.932 & -3.341 \\
\hline 定数 & -4.276 & 1.319 & -3.242 \\
\hline
\end{tabular}

表-6 自動車選択確率(Pcar)の説明要因

\begin{tabular}{|c|c|c|c|}
\hline 説明変数 & 偏回帰係数 & 標準誤差 & T値 \\
\hline ゾーン間距離(Log) & -0.827 & 0.167 & -4.956 \\
\hline 駐車台数 O & 0.423 & 0.143 & 2.958 \\
\hline 住宅密度 O & -5.582 & 1.207 & -4.623 \\
\hline 住宅密度 D & -3.343 & 1.233 & -2.712 \\
\hline 商業密度 O & -1.037 & 0.474 & -2.188 \\
\hline 事務所密度 O & -2.403 & 1.250 & -1.922 \\
\hline 定数 & 4.941 & 0.499 & 9.902 \\
\hline
\end{tabular}

この時，各ゾーン当たりの自動車エネルギー消費量に 着目すると, 1992 年現況の值と TransCAD を用いた推計 值との相関は 0.908 となった. なお， 1992 年現況の值は 宇都宮 PT 調査 ${ }^{25)}$ による交通手段別 OD 表から式(4)をも とに計算した.

\section{4. コンパクトシティ政策評価の条件整備}

\section{(1) 宇都宮市における将来人口予測}

家庭部門の電力消費量と人口は非常に高い相関がある ことから, 本研究では, まず宇都宮市の町別 (246 地区) 将来人口を推計した。 また，宇都宮市の人口は全国平均 と同様に，2006 年頃にピークを迎え，その後減少傾向に 転ずると予想されていることから，その減少傾向が明確 となる 2020 年を本研究の評価年次に設定した（図-6 参 照 ${ }^{26)}$.

人口予測方法の基本はトレンド型モデルとし, 表-7 に 示す 3 種類の方法を用いて，各々の町が決定係数(R2)の 高い方法で予測できるよう行った ${ }^{\text {注 }}$. なお，推定年次の 宇都宮市全体の人口をコントロールトータルとし, 246 町の推定結果の合計に一致させている.

人口予測結果(2002-2020の人口増加率)を図-7に示す.

\section{(2)エリア区分と政策の仮定}

コンパクトシティを表現するに当たり，宇都宮市 246 地区を都心からの距離に応じて都心エリア・近郊エリ ア・郊外エリアの三つに分類する(図-8). また, 本研究 では「コンパクト」を都心周辺の人口密度が高い状態と 考える.ここで，都心部への人口再集積方法として住宅

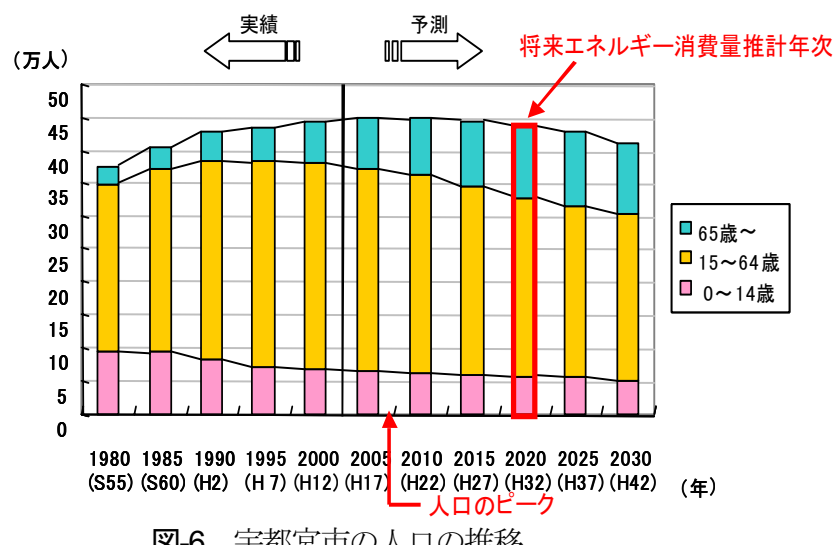

表-7 人口予測方法

\begin{tabular}{|c|c|c|c|}
\hline $\begin{array}{c}\text { 人口増加率 } A(\%) \\
(H 11 \sim H 15)\end{array}$ & 予測方法 & 式 & 町数 \\
\hline$A \geqq 5$ & ロジステイツク曲線 & $Y=\gamma /(1+\mathrm{e} \alpha-\beta \mathrm{t})$ & 44 \\
\hline$-10<\mathrm{A}<5$ & 線形近似法 & $\mathrm{Y}=\mathrm{f}(\mathrm{t})+\mathrm{c}$ & 176 \\
\hline $\mathrm{A} \leqq-10$ & 累乗近似法 & $\mathrm{Y}=\{\mathrm{f}(\mathrm{t})\}^{\mathrm{n}}$ & 26 \\
\hline
\end{tabular}




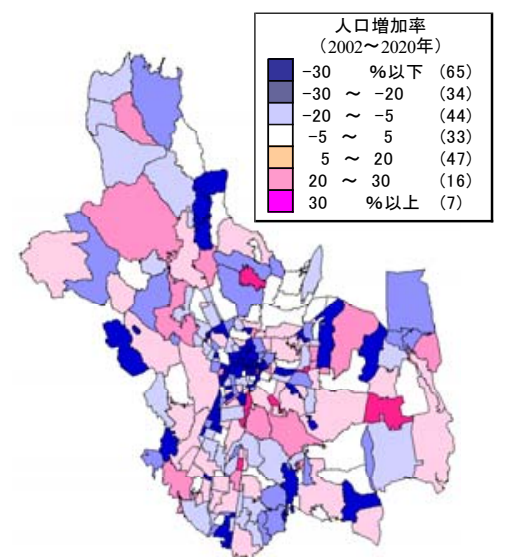

図-7 宇都宮市人口増加率

(2002-2020)

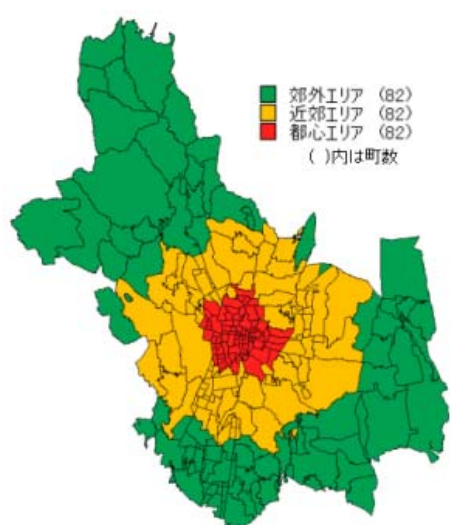

図-8 宇都宮市のエリア区分図

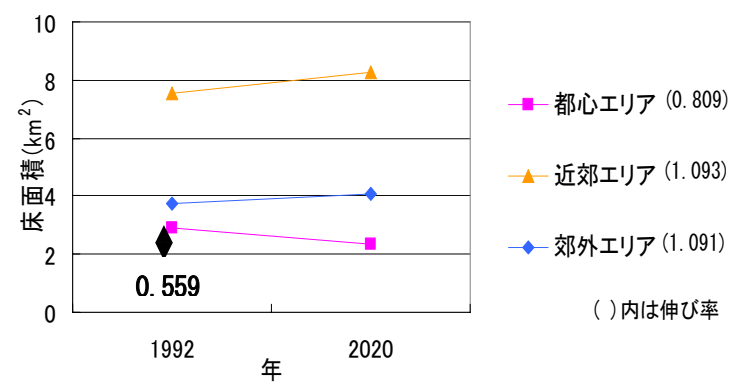

図-9 住宅床面積の推移(1992-2020)

表-8 各シナリオの都心エリアの誘導力設定と床面積の変化

\begin{tabular}{|c|c|c|c|}
\hline シナリオ & 伸び率 & $\begin{array}{c}\text { 床面積 } \\
\left(\mathrm{km}^{2}\right)\end{array}$ & $\begin{array}{c}\text { 増加床面積 } \\
\left(\mathrm{km}^{2}\right)\end{array}$ \\
\hline 0 & 0.809 & 2.361 & - \\
\hline 1 & 1.000 & 2.920 & 0.559 \\
\hline 2 & 1.101 & 3.479 & 1.118 \\
\hline
\end{tabular}

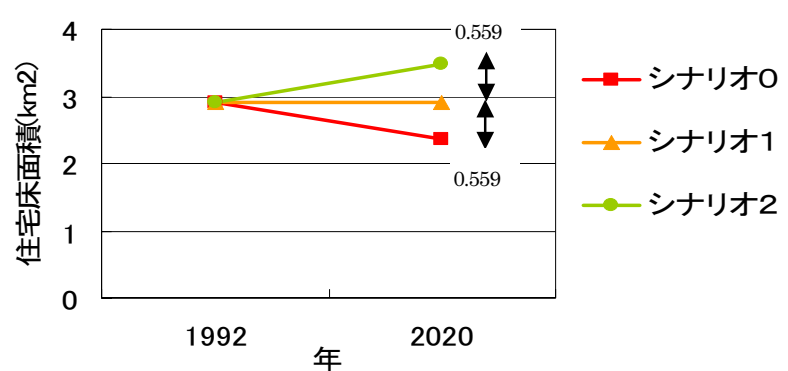

図-10 各シナリオにおける住宅床面積の変化

費補助注6 および住宅供給促進が挙げられる．よって，本 研究では都心エリアにおいて住宅供給・家賃補助等を行 うことにより, 住宅床面積の増加を誘導したと仮定する.

一方で，郊外エリアにおいて開発許可の規制等により 住宅床面積の増加を規制することでコンパクトシティを 表現する．以上の仮定の下，郊外エリアの戸建住宅から 都心エリアの集合住宅へ移住が行われた場合のエネルギ 一消費量の変化を算出する.

\section{(3) 住宅床面積の変化とシナリオ設定}

2020 年町別予測人口を用いて 2020 年住宅床面積を予 測し, 1992 年からの推移を図-9 に示す.

これより，都心エリアで減少傾向，近郊・郊外エリア で増加傾向を示すことが分かる．本研究では，都心エリ アの床面積の変化に着目し，床面積が減少する現状推移 （シナリオ０）に加え，床面積を変化させない場合(現状 維持)のシナリオ 1 を設定する.さらに床面積を減少分だ け増加させる場合（シナリオ 2 ）を設定する. シナリオ 0〜2 の床面積の変化を表-8, 図-10に示寸，これをみる と, 都心居住を推進したシナリオ2では1992年時点の住宅 床面積より,都心エリアで約1割の増加があったと仮定し ていることになる.
表-9 設定パターンの内訳

\begin{tabular}{|c|c|c|}
\multicolumn{3}{c}{ 表-9 設定パターンの内訳 } \\
\begin{tabular}{|c|c|c|}
\hline パーン & 移住構成(郊外一都心) & 移住世帯 \\
\hline $\mathrm{A}$ & 都心エリア型構成比 & 単身世帯中心 \\
\hline $\mathrm{B}$ & 郊外エリア型構成比 & 夫婦と子供世帯中心 \\
\hline
\end{tabular}
\end{tabular}

表-10 各エリアの世帯構成比率

\begin{tabular}{|c|c|c|c|c|}
\hline \multirow{2}{*}{ エリア 世 帯 } & \multicolumn{4}{|c|}{ 世帯構成(\%) } \\
\cline { 2 - 5 } & 単身世帯 & 夫婦世帯 & 夫婦と子供世帯 & 三世代世帯 \\
\hline \hline 都心Iリア & 48.7 & 18.1 & 24.9 & 8.3 \\
\hline 近郊Iリア & 41.9 & 17.1 & 32.6 & 8.3 \\
\hline 郊外エリア & 29.9 & 17.2 & 38.1 & 14.9 \\
\hline
\end{tabular}

\section{(4) パターンの設定}

次に，移住する住宅種別をパターンとして設定するこ とで，ライフスタイルの影響を検討する。ここではシナ リオ 1 における都心エリアでの増加床面積 $\left(0.559 \mathrm{~km}^{2}\right)$ に, 郊外の戸建住宅から都心の集合住宅への世帯の移住を設 定する.

つまり, 都心エリアの家族構成別の世帯数構成比(単身 世帯が多い構成比)で移住を行った場合(パターンA)と郊 外エリアの構成比(夫婦と子供世帯が多い構成比)で行っ 
た場合(パターンB)について検証を行う.この設定パター ンの内訳を表-9に, 各エリアの世帯構成の比率を表-10 に示寸．また，郊外エリアからの移住については，郊外 エリアに存在する全ての町を対象に, 各町単位の人口比 に応分した移住数を 4 種類の世帯構成毎に算出した.なお, 設定したパターンはシナリオとの組み合わせで，本文中 にはシナリオ $1 \mathrm{~A}$ のように表記する.

\section{5. コンパクトシティ政策評価}

\section{(1) シナリオ0の評価}

無政策の現状推移(シナリオ0)における宇都宮市のエ ネルギー消費量の変化を表-11に示寸.これにより, 人口 の減少の影響を受け, 民生部門 (電力消費), 運輸部門 (自 動車エネルギー消費）ともに，エネルギー消費量がわず かに減少していることが分かる.

\section{(2) シナリオ 1 の評価}

シナリオ 0 を基準としたシナリオ 1 における電力消費 量の変化を図-11に示寸. これより, 都心で増加する電力 消費量に比へ，郊外で減少する電力消費量が多いため, 宇都宮市全体では電力消費量が減少していることが分か る. また, 宇都宮市全体の電力消費減少量がシナリオ 1 $\mathrm{B}$ に比べ, シナリオ $1 \mathrm{~A}$ 方が多いことから, 夫婦と子供 世帯を多く移住させるよりは, 郊外の戸建住宅に住む単

表-11 シナリオ0のエネルギー消費量比較(1 日当たり)

\begin{tabular}{|c|c|c||c|}
\hline 単位: $\left[10^{5} \mathrm{kcal} /\right.$ 日] & 現況 & シナリオ0 & 変化率 \\
\hline 電力消費量 & 15,009 & 14,809 & 0.987 \\
\hline 自動車エネルギー消費量 & 9,130 & 8,940 & 0.979 \\
\hline
\end{tabular}

身世帯を多く都心部の集合住宅一移住させることにより 電力消費削減効果が大きくなると考えられる. また，運 輸部門におけるトリップ数の変化を図-12に示す.これよ り, コンパクトシティ政策により, 自動車トリップ数は 減少し, 徒歩・二輪車, 公共交通トリップは増加するこ とが確認できた. 次に, 移住した世帯数と各部門の減少 エネルギー消費量がシナリオ 0 の宇都宮市全体に占める 割合を表-11に示す. エネルギーの減少量は, 宇都宮市全 体でみると,何もしなかった場合に比べて,それぞれ $2 \%$ 〜3\%の削減となり, 現状からすると約 $5 \%$ 程度の削減が 見込まれることになる.

\section{(3) シナリオ 2 の評価}

シナリオ 2 における電力消費量の変化を図-11に示す. このシナリオにおいては, シナリオ 1 で移動した世帯 数の2倍の世帯数を移動させているため, 電力消費量の削 減効果も単純に2倍となっている.

一方で，運輸部門の変化は図-12 のように，交通手段 別に異なった傾向をみせる. 公共交通の選択確率は住宅 密度が上がると上昇するようなモデル構造となっている ので, 都心居住者の増加によって公共交通のトリップ数 はシナリオ 1 に比べて大きく増加するが, 肝心の自動車 トリップ数の減少幅が 2 倍より少なくなっている. 運輸 部門のエネルギー消費の大半が自動車利用によるため, エネルギー削減の総量はシナリオ 1 の 2 倍には達してい ない.

\section{(4) まとめ}

\section{a) 民生部門}

図-11 より，電力消費量削減効果が最も大きいのはシ ナリオ $2 \mathrm{~A}$ である. 各種家庭の電力消費量からも分かる ように, 戸建住宅に単身や夫婦だけで住むことは, 電力

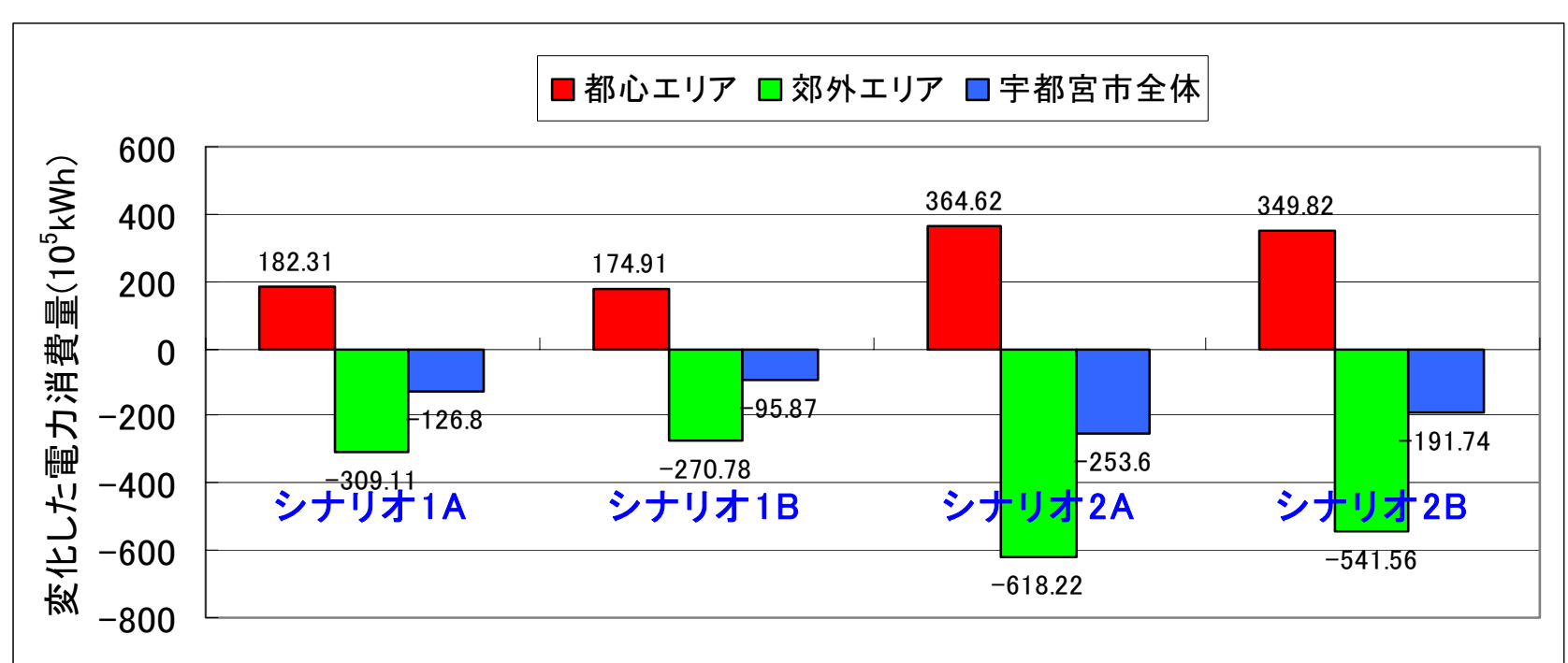

図-11 各シナリオにおける 1 日当たりの電力消費量の変化（民生部門） 


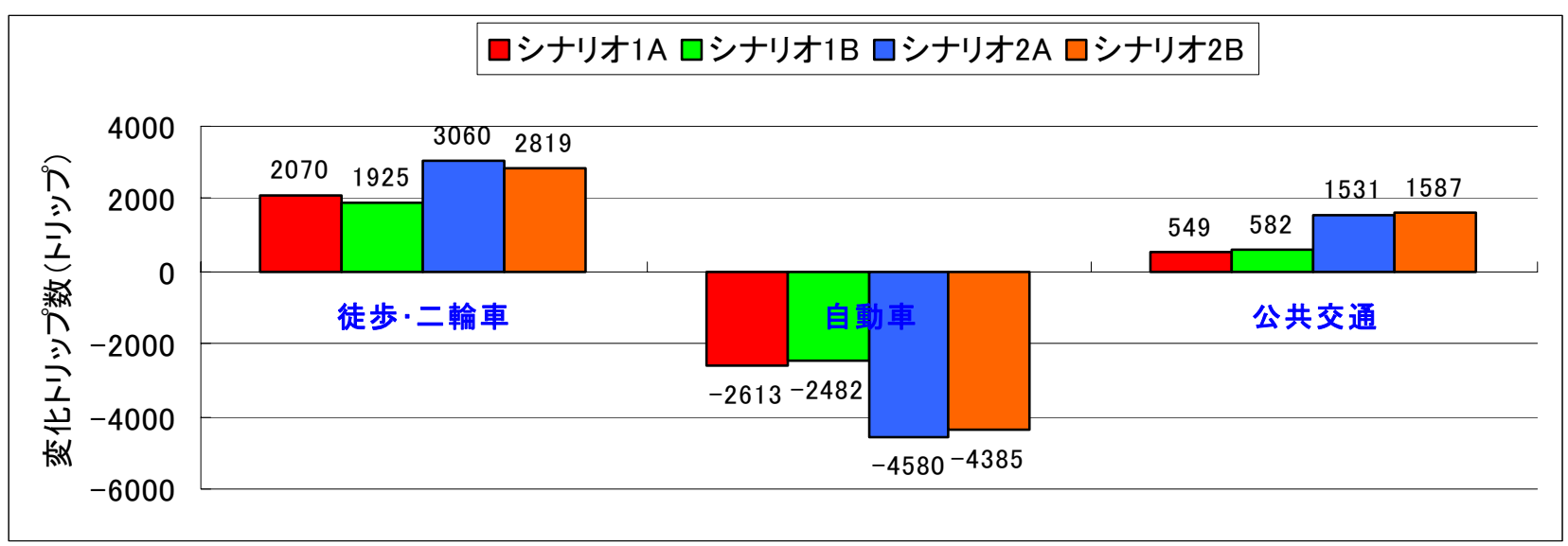

図-12 各シナリオにおける交通手段別 1 日当たりのトリップ数の変化（運輸部門）

表-12 移住世帯数と減少エネルギー消費量変化の割合

\begin{tabular}{|c|c|c|c|c|c|}
\hline \multicolumn{2}{|c|}{ (単位:\%) シナリオ } & $\begin{array}{l}\text { シナリオ } \\
1 \mathrm{~A}\end{array}$ & $\begin{array}{c}\text { シナリオ } \\
1 \mathrm{~B}\end{array}$ & $\begin{array}{c}\text { シナリオ } \\
2 \mathrm{~A}\end{array}$ & $\begin{array}{l}\text { シナリオ } \\
2 \mathrm{~B}\end{array}$ \\
\hline \multicolumn{2}{|c|}{ 移住させた世帯の割合 } & 4.09 & 3.26 & 8.18 & 6.52 \\
\hline \multirow{2}{*}{$\begin{array}{l}\text { シナリオOからのエネル } \\
\text { ギ一消費量の減少割合 }\end{array}$} & 電力 & 2.02 & 1.53 & 4.04 & 3.06 \\
\hline & 自動車 & 2.57 & 2.48 & 4.20 & 4.10 \\
\hline
\end{tabular}

消費量の観点からは非常に非効率である.このことは, シナリオ Bよりシナリオ A の方が, 電力消費量削減効果 が大きいことにも表れている.また，各シナリオにおい て，移住世帯数と電力の減少量が宇都宮市全体に占める 割合を表-10 に示す。これより，シナリオ $1 \mathrm{~A}$ では宇都 宮市の世帯約 4.1\%の移住を促すことにより，何もしな い場合に比べて約 $2.0 \%$ の電力消費量の削減が見込める という結果となった.

\section{b) 運輸部門}

図-12 より, 自動車のトリップ数が最も減少するのは シナリオ $2 \mathrm{~A}$ であり，自動車エネルギー消費量も最も低 くなっている. 各シナリオにおいて，移住世帯数と自動 車エネルギー消費量の減少量が宇都宮市全体に占める割 合を示す表-12 より, シナリオ $1 \mathrm{~A}$ では宇都宮市の世帯の 約 $4.1 \%$ の移住を促すことにより, 約 $2.6 \%$ の自動車エネ ルギー消費量の削減が見込めるという結果となった。し かし，機関分担率の変化 (図-13 参照) における現況再 現の值と比較すると，宇都宮市全体でのエネルギ一消費 量はシナリオ $2 \mathrm{~A}$ の方が少ないが，自動車分担率は現況 再現の方が低い. エネルギー消費量の削減は全体の人口 減少によって引き起こされており，一部の居住地移転の みで, 現状まで自動車分担率を下げる効果は見込めない. 都市全体の自動車依存度を低下させるためには，さらな る土地利用政策と共に LRT 等の公共交通の充実が重要 であると考えられる。

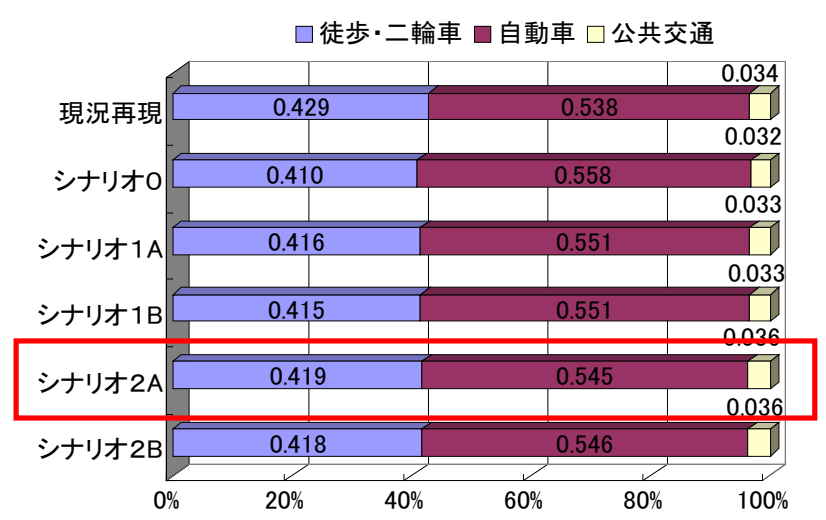

図-13 各シナリオにおける機関分担率の変化

\section{6. おわりに}

コンパクト化に伴う人口密度の変化がエネルギー消費 に与える影響は，どのような特性の世帯が，都市のどの 場所で変動するかに大きな関係がある. 本研究では，コ ンパクトシティ政策を行った際の電力消費量および自動 車エネルギー消費量の変化を算出した．宇都宮市全体で みると小さいが，両部門において確かにエネルギ一消費 量低減効果が見込めることが確認できた。

特に，単身・夫婦世帯の戸建住宅から集合住宅への移 住が効果的である。一方で，家庭部門においては核家族 化を抑制し，三世代居住を促すことで住宅空間の共同利 用を図ることが重要であると言える。また，運輸部門に おいては，自動車エネルギー消費量が減少するが，公共 
交通を整備することにより，より一層のエネルギー消費 量低減が期待される.

具体的には，郊外の戸建住宅に住む単身・夫婦世帯を 都心部の集合住宅に移住させて，かつ，核家族化を抑制 することが重要であると考えられる．しかしながら，現 実的には,このようなライフスタイルの問題として, 人々 は郊外の広い戸建住宅を好むという傾向が見られ，コン パクトシティの実現には問題も多い.

従って，郊外での開発を規制し，都心エリアでの居住 を促進する方策を進めるとともに，都心を居住地として 魅力的なものにして，郊外化した人々をいかに都心に引 きつけるかが大きな問題であると考えられる.

なお，本研究では，民生エネルギーに関しては電力消 費のみを，運輸エネルギーに関しては自動車のみを対象 とし，かつ，帰宅トリップのみで表現をしている.この ため, コンパクトシティを総合的に評価するためには他 のエネルギー源や交通手段・交通目的についても分析す る必要がある注7。ただし, 各種のエネルギ一消費量を合 算して評価する際には，エネルギー消費のメカニズムに 十分に留意しつつ，政策との関連性を検討することが重 要である. 総合的なアプローチについては今後の課題で ある.

謝辞 : 本研究は東京電力と宇都宮大学との共同研究の成 果の一部であり，分析・集計等において今村麻希氏（東 京電力), 松村明子氏 (東電設計) の多大な協力を得まし た. 記して謝意を表します。

\section{補注}

1) 一般に家庭で利用されている電気料金メニューは「電灯」 と「電力」があり, 前者はご家庭で照明や家電製品に使う 電気で, 後者は電気温水器やエコキュート等, 深夜に使う 電気のことである.ここ数年, 全電化住宅の普及により後 者の「電力」の需要は高まってはきているが, 家庭での電 力需要を総じて評価すると, 家庭での電力消費量について は，現状では「電灯」がそのほとんどを占めているため， 本論分では「電灯」の夕を家庭での消費電力として取り扱 うこととする.

2) 本調查は電力情報の開示について署名捺印が必要な調查 で, データ収集のため多様な調査方法を用いた. そのため, 署名捺印に応じた被験者のバイアスが想定される. なお， アンケートのサンプルの内訳は，単身世帯 $21 \%$ ，夫婦世帯 $22 \%$, 夫婦と子供世帯 $41 \%$, 三世代以上の世帯 $16 \%$ である.

3) アンケート調査結果より算出した電力消費原単位のうち, 集合住宅の 3 世代以上世帯については, サンプルはないが, 移住によるエネルギー消費量の評価を行う上で必要である
ため比例配分による推定值を参考として示した.

4) ただし, 原単位を一定としたこの手法では渋滞によるエネ ルギー消費量の増大が，所要時間にのみ依存することに注 意が必要である．また，PT 調査の特性上，物資流動につい ては十分に再現できていないため留意する必要がある.

5) 町丁別の人口予測モデルは過去 5 年間分（1999-2003 年） の実データを用いて構築した. 2003 年時点での推計值と実 測值の誤差は, 平均 11.5 人, 分散 292.6 で, 推計值と実測 值の相関係数は 0.99 であった.

6) 宇都宮市では若年夫婦世帯家賃補助制度 (中心市街地以外 の区域から中心市街地内にある民間賃貸住宅へ転居又は転 入した, 40 歳未満の若年夫婦世帯に対して, 実質家賃額の $1 / 2$ を月額 3 万円および 60 箇月を限度に家賃補助）を現在 実施中.

7) 一般的に, 家庭 1 世帯当たり（電気・ガス併用住宅）にお ける全エネルギー消費量のうち自動車ガソリン消費量（自 動車) は約 $53 \%$ ，電力消費量は約 $28 \%$ で合計 $81 \%$ 程度(2001 年）となる. 参考 : 経済産業省HPより

http://www.meti.go.jp/intro/kids/kankyo/kankyo05_01.html

\section{参考文献}

1) Newman, P.W.G. and Kenworthy, J.R.: Cities and Automobile Dependence, A Source book, Gower Technical, 1989.

2) Bouwman, M.E.: Changing mobility patterns in a compact city: Environmental impacts, Compact Cities and Sustainable Urban Development, Ashgate, pp.229-240, 2000.

3) Brindle R.E.: Lies, Damned Lies and "Automobile Dependence" some hyperbolic reflections, Australian Transport Research Forum 19, pp.117-131, 1994.

4) 鈴木崇正, 室町泰徳: メガシティを対象とした人口密度と自 動車利用の相互関係に関する再検討一都市面積と自動車利 用距離に着目して一日本都市計画学会学術研究論文集, No.41-3, pp.151-156, 2006.

5) 林良嗣, 冨田安夫, 土井健司, スパラット・リチカ, 加藤博 和 : 都市交通によるエネルギー消費および環境負荷への影響 に関する比較, 土木計画学研究·講演集, No.15(1), pp.939-944, 1992.

6) 谷口 守, 村川威臣, 森田哲夫 : 個人行動データを用いた都 市特性亡自動車利用量の関連分析, 都市計画論文, No.34, pp.967-972, 1999.

7) 森本章倫, 古池弘隆 : 都市構造が運輸エネルギーに及ぼす影 響に関する研究, 第 30 回日本都市計画学会学術研究論文集, pp.685-690, 1995.

8) 小根山裕之, 大西博文: 環境負荷の小さい都市構造・交通体 系に関する一考察, 土木計画学研究・講演集, No.20(2), pp.129-132, 1997.

9) 堀裕人, 細見昭, 黒川洸: 自動車エネルギー消費量から見た コンパクトシティに関する研究—宇都宮都市圈の 2 時点にお ける PT データを用いて一, 日本都市計画学術研究論文集, 第34 回, 1999.

10) 森本章倫, 小美野智紀, 品川純一, 森田哲夫 : 東京都市圈 におけるPT データを用いた輸送エネルギー推計と都市構造 に関する実証的研究, 土木計画学研究 - 論文集, No.13, pp.361-368, 1996.

11) 北村隆一, 山本俊行, 神尾亮: 高密度都市圈での交通エネ ルギー消費削減に向けた土地利用政策の有効性，土木学会論 
文集，No.625/IV-44，pp.171-180，1999.

12) 佐保肇 : 中小都市における都市構造のコンパクト性に関す る研究, 日本都市計画学会学術研究論文集, 第33回, pp.73-78, 1998.

13) 森本章倫 : 土地利用と交通の関連性からコンパクトな市街 地を考える，交通工学，Vol.37，増刊号，pp.9-14， 2002.

14) 石田健一: 戸建住宅のエネルギー消費量, 日本建築学会計 画系論文集，第501 号, pp.29-36, 1997.

15) 鈴木勉: 全国主要都市におけるエネルギー消費構造に関す る比較分析, 日本都市計画学会学術研究論文集, 第 31 回, 1996.

16) 今村麻希, 森本章倫, 古池弘隆, 中井秀信 : 都市形態から みた家庭部門の電力消費量と自動車のエネルギー消費量に 関する研究, 土木計画学研究論文集, Vol.21, pp.283-288, 2004.

17) 石森大輔, 森本章倫, 古池弘隆, 中井秀信 : 家庭部門の電 力消費量に影響を及ぼす地域特性に関する研究, 土木計画学 研究講演集, Vol.29, CD:全 4p, 2004.

18) 中道久美子, 島岡明生, 谷口守, 松中亮治 : サステイナビ リティ実現のための自動車依存特性に関する研究, 都市計画 論文集，No.40-3， pp.37-42， 2005.

19) 田頭直人 : 都市の空間構造とエネルギーに関する一考察一 エネルギー削減を目指した諸システムの導入効果について 一, 第 33 回日本都市計画学会学術研究論文集, pp.61-66, 1998. 20）国土交通省国土交通政策研究所，環境負荷の少ない都市・
国土構造に関する研究一首都圈モデル一, 国土交通政策研究 第 14 号, 2002.

21）桐山孝晴，片岡孝博，都市環境施策効果の定量評価，PRI Review，第 6 号, pp.21-25, 2002.

22) 森本章倫 : 交通環境負荷とコンパクトシティに関する研究 動向と課題, 土木計画学研究講演集, No.25, CD:全 4p, 2002.

23) 森本章倫, 古池弘隆: : 交通エネルギー消費の推移と都市構 造に関寸る研究, 土木計画学研究講演集, No. 25, CD:全 $4 p$, 2002.

24) TransCAD4.0 : http://www.caliper.com/tcovu.htm

25) 第2回宇都宮都市圈PT調査(1992)

26) 宇都宮市統計データバンク :

http://www2.city.utsunomiya.tochigi.jp/DataBank/index.htm

27) 川島智彦，古池弘隆，森本章倫 : 都市特性からみた輸送工 ネルギー原単位の推計に関する研究，第 17 回交通工学研究 発表会論文報告集，pp.149-152，1997.

28) 海道清信 : コンパクトシティ一持続可能な都市の社会像を 求めて, 学芸出版社,2001.

29) 資源エネルギー庁 : エネルギー2002

30) 日本の統計 2005 (総務省総務局)

31) 平成12年度国勢調查（総務省）

32) 数表でみる東京電力 (平成16年度版, 東京電力(株))

(2007.1.17受付)

\section{A STUDY ON THE ENERGY CONSUMPTION IN RESIDENTIAL AND TRAFFIC SECTOR IN CASE OF PRACTICING A COMPACT CITY POLICY}

\section{Hidenobu NAKAI and Akinori MORIMOTO}

In this paper, we focus on the change of the electric power consumption and automobile energy consumption in residential sector in case of implementing a compact-city policy. We could check the reduction effectiveness of the both energy consumption was possible in the case. In particular, the migration to collective housing from the individual house of singleness and a husband-and-wife household is effective. On the other hand, in national life section, control of nuclear family and promotion of three-generation habitation is very important. And, in a transportation section, automobile energy consumption decreases, and much more energy consumption reduction is expected by maintenance of public transportation. 